\title{
UPAYA MENINGKATKAN KEMAMPUAN MENDESKRIPSIKAN KEPATUHAN TERHADAP HUKUM MELALUI MODEL PEMBELAJARAN KOOPERATIF TIPE STAD BAGI SISWA DI KELAS IX SMP NEGERI 9 TEBING TINGGI
}

\author{
Rahmawati Hasibuan
}

Surel : rahmawati006spd@gmail.com

\begin{abstract}
ABSTRAK
Penelitian ini bertujuan untuk meningkatkan ketuntasan dan prestasi belajar pada mata pelajaran Pendidikan Kewarganegaraan melalui Model Pembelajaran Kooperatif Tipe STAD. Objek penelitian adalah siswa kelas IX SMP Negeri 9 Tebing Tinggi yang berjumlah 40 siswa. Penelitian terdiri atas 2 siklus yang disebut dengan siklus 1 dan siklus 2. Dari aspek partisipasi siswa dalam pembelajaran pada siklus kedua semua aspek mengalami peningkatan yang cukup signifika. Semua siswa sudah terlibat dan aktif berdiskusi untuk memecahkan masalah sudah mencapai 39 (97,5\%). Secara ringkas dapat disimpulkan bahwa hasil siklus kedua dari aspek partisipasi/keaktifan siswa dalam proses pembelajaran sudah tercapai secara optimal, sebab rata-rata persentase yang dicapai sudah 93,43\%. Pada siklus kedua, persentase ketuntasan belajar siswa juga meningkat yaitu dari 40 siswa pada siklus pertama hanya 30 siswa yang termasuk dalam kategori sudah tuntas belajar menjadi 39 siswa. Sehingga pada siklus kedua ini persentase kelulusan siswa sudah mencapai $93,43 \%$.
\end{abstract}

Kata Kunci: Metode tipe STAD, Belajar, hasil belajar

\section{PENDAHULUAN}

Metode belajar Pendidikan Kewarganegaraan yang digunakan di SMP Negeri 9 Tebing Tinggi selama ini adalah metode ceramah, tanya jawab, kerja kelompok dan pemberian tugas, Metode tersebut dirasakan kurang mendukung ketuntasan dan prestasi belajar yang maksimal. Sehingga guru harus melaksanakan remedial. Hasil evaluasi yang diamati peneliti tiga tahun terakhir menunjukan bahwa siswa yang belajar tuntas Pendidikan Kewarganegaraan dan memperoleh nilai 0-74 rata-rata 29\%. Sedangkan Kriteria Ketuntasan Minimal (KKM) Pendidikan Kewarganegaraan di SMP Negeri 9 Tebing Tinggi adalah $75 \%$ untuk seluruh siswa atau minimal nilai 70. Peneliti yang mengajar di kelas IX "Mendeskripsikan Kepatuhan Terhadap Hukum", selama ini dengan metode pembelajaran Ceramah, Tanya Jawab, Pemberian Tugas terstruktur dan mandiri, dan Eksplorasi ternyata tidak dapat membangkitkan minat dan pemahaman siswa terhadap "Mendeskripsikan Kepatuhan Terhadap Hukum".

Tujuan diadakannya pnelitian ini untuk mengetahui "Kepatuhan Terhadap Hukum", pada PBM Pendidikan Kewarganegaraan di kelas IX SMP Negeri 9 Tebing Tinggi dengan model pembelajaran Kooperatif Tipe STAD. Menganalisis bagaimana siswa menyikapi 

relevansi penerapan model pembelajaran Kooperatif Tipe STAD pada PBM Pendidikan Kewarganegaraan dalam meningkatkan ketuntasan dan prestasi belajarnya.

\section{METODE PENELITIAN}

Penelitian ini termasuk dalam kategori Penelitian Tindakan (action research), karena penelitian ini dilakukan untuk memecahkan masalah pembelajaran baik di kelas maupun di lapangan (luar kelas).

Penelitian Tindakan Kelas ini dilakukan di SMP Negeri 9 Tebing Tinggi Tahun Pembelajaran
2015/2016 pada bulan AgustusDesember 2015. Objek penelitian adalah siswa kelas IX SMP Negeri 9 Tebing Tinggi yang berjumlah 40 siswa.

Rancangan penelitian adalah Penelitian Tindakan Kelas (PTK). Penelitian terdiri atas 2 siklus yang disebut dengan siklus 1 dan siklus 2 .

Prosedur atau langkah-langkah yang akan dilakukan dalam penelitian ini dilaksanakan dalam kegiatan dengan model Kemmis dan Taggart (dalam Sugiarti, 1997:6), seperti bagan berikut:

\section{Model PenelitianTindakan Kelas}

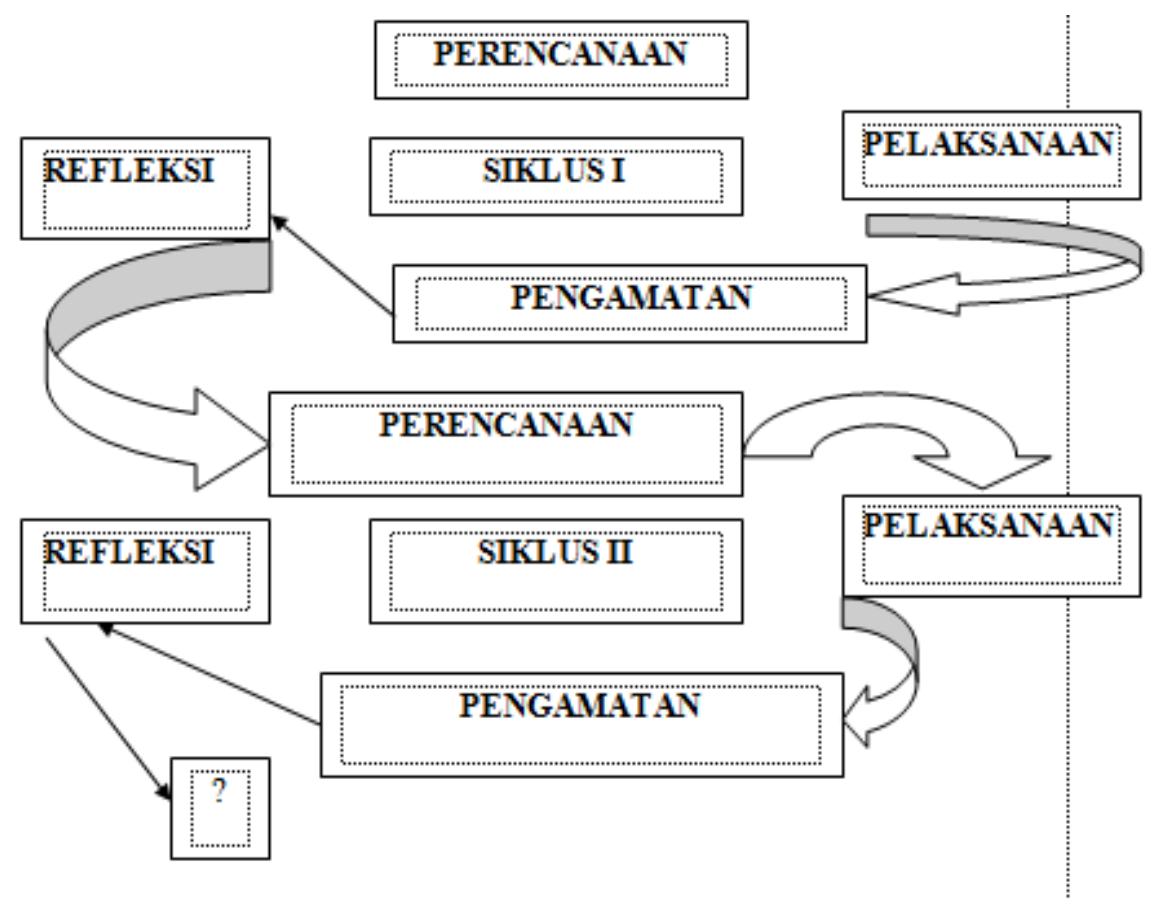

Konsep aksi pada action research Penelitian Tindakan Kelas

Diadopsi dari Hopkin (1995) setelah dimodifikasi 
Kegiatan pada setiap tahapan siklus adalah sebagai berikut:

Pada tahap perencanaan ini, peneliti melakukan beberapa aktivitas yaitu:

a. Membuat RPP.

b. Menganalisis materi pelajaran .

c. Menyiapkan objek lingkungan.

d. Peneliti melakukan koordinasi dengan Kepala Sekolah (manager sekolah).

e. Menyiapkan lembar pengamatan atau observasi.

f. Menyusun lembar observasi, Pelaksanaan Tindakan

Pada tahap implementasi pelaksanaan tindakan ini guru melakukan Model Pembelajaran Kooperatif Tipe STAD di dalam ruangan kelas dengan menggunakan panduan perencanaan yang telah dibuat.

Guru/peneliti sekaligus observator dibantu oleh beberapa alat perekam, pencatat, dan lembar observasi untuk menyelesaikan tujuan penelitian,

Data yang diperoleh pada lembar observasi, dianalisis. Kemudian dilakukan refleksi. Pelaksanaan refleksi merupakan hasil observasi/pengamatan peneliti pada saat melakukan observasi Model Pembelajaran Kooperatif Tipe STAD yang bertujuan untuk mengevaluasi hasil tindakan yang telah dilakukan.

Selanjutnya, Pada siklus kedua ini juga diadakan perencanaan seperti pada siklus satu yaitu tahap perencanaan, tindakan, observasi dan refleksi.
Dengan memperhatikan hasil refleksi yang terjadi pada siklus satu maka rencana tindakan yang dilakukan pada siklus dua ini adalah sebagai berikut:

a. Membuat RPP.

b. Menyiapkan siswa menjadi agar terbuka.

c. Peneliti melakukan koordinasi dengan Kepala Sekolah (manager sekolah).

d. Menyiapkan lembar pengamatan atau observasi.

e. Menyusun lembar observasi.

Pada implementasi pelaksanaan tindakan ini guru melakukan pembelajaran di dalam kelas dengan menggunakan panduan perencanaan yang telah dibuat.Observasi

Guru/peneliti sekaligus sebagai observatory dibantu oleh materi ajar dan alat observatory lainnya melakukan observasi/pengamatan terhadap semua kejadian pada proses Model Pembelajaran Kooperatif Tipe STAD untuk dijadikan acuan dalam membuat catatan (Vignette) dan pengisian lembar observasi.

Data yang diperoleh pada lembar observasi, dianalisis secara lebih dalam dan tajam pada siklus kedua ini.Kemudian dilakukan refleksi atau perenungan.Instrumen Penelitian

Instrumen yang digunakan dalam penelitian ini terdiri dari:

a. Silabus

b. Rencana Pelaksanaan

Pembelajaran (RPP)

c. Lembar Kegiatan Siswa 
d. Lembar Observasi Kegiatan Model

Pembelajaran

Kooperatif Tipe STAD

e. Tes Formatif

\section{HASIL PENELITIAN DAN PEMBAHASAN}

Untuk mengetahui hasil penelitian, langkah pertama yang dilakukan peneliti adalah mengidentifikasi masalah melalui pengamatan proses belajar mengajar yakni rendahnya kemampuan siswa.

Tabel Hasil Observasi Kondisi Awal Partisipasi Siswa dala Proses Pembelajaran

\begin{tabular}{|c|c|c|c|}
\hline No & Aspek yang diamati & Jumlah Siswa & Persen \\
\hline 1 & $\begin{array}{l}\text { Mendengarkan penjelasan guru } \\
\text { dengan tekun }\end{array}$ & 33 & 82,5 \\
\hline 2 & $\begin{array}{l}\text { Ada usaha dan motivasi untuk } \\
\text { mempelajari bahan pelajaran atau } \\
\text { stimulus yang diberikan oleh guru }\end{array}$ & 14 & 35 \\
\hline 3 & $\begin{array}{l}\text { Dapat menjawab pertanyaan yang } \\
\text { diberikan oleh guru dengan benar pada } \\
\text { akhir pelajaran }\end{array}$ & 17 & 40,5 \\
\hline 4 & $\begin{array}{l}\text { Dapat bekerja sama dan berhubungan } \\
\text { dengan siswa lain }\end{array}$ & 19 & 47,5 \\
\hline 5 & $\begin{array}{l}\text { Mengajukan pendapat, bertanya } \\
\text { berkomentar kepada guru dan siswa }\end{array}$ & 6 & 15 \\
\hline 6 & $\begin{array}{l}\text { Aktif berdiskusi untuk memecahkan } \\
\text { masalah }\end{array}$ & 8 & 20 \\
\hline 7 & $\begin{array}{l}\text { Mengerjakan tugas yang } \\
\text { oleh guru dan mampu merikan } \\
\text { simpulan sendiri tentang pelajaran } \\
\text { yang diterimanya }\end{array}$ & 10 & 25 \\
\hline 8 & Hasil belajar tuntas & 25 & 62,5 \\
\hline & Rata-rata & & 41,25 \\
\hline
\end{tabular}

Dalam penelitian ini ada dua penelitian proses pembelajaran dan aspek yang ingin diukur yaitu hasil pembelajaran .

\begin{tabular}{|c|l|c|c|}
\hline No & \multicolumn{1}{|c|}{ Aspek yang diamati Jumlah Siswa } & Persen \\
\hline 1 & $\begin{array}{l}\text { Mendengarkan penjelasan guru } \\
\text { dengan tekun }\end{array}$ & 38 & 95 \\
\hline 2 & $\begin{array}{l}\text { Ada usaha dan motivasi untuk } \\
\text { mempelajari bahan pelajaran atau } \\
\text { stimulus yang diberikan oleh guru }\end{array}$ & 27 & 65 \\
\hline 3 & $\begin{array}{l}\text { Dapat menjawab pertanyaan yang } \\
\text { diberikan oleh guru dengan benar pada } \\
\text { akhir pelajaran }\end{array}$ & 27 & 65 \\
\hline
\end{tabular}


Rahmawati Hasibuan : Upaya Meningkatkan ....

\begin{tabular}{|c|l|c|c|}
\hline 4 & $\begin{array}{l}\text { Dapat bekerja sama dan berhubungan } \\
\text { dengan siswa lain }\end{array}$ & 26 & 65 \\
\hline 5 & $\begin{array}{l}\text { Mengajukan pendapat, bertanya } \\
\text { berkomentar kepada guru dan siswa }\end{array}$ & 18 & 45 \\
\hline 6 & $\begin{array}{l}\text { Aktif berdiskusi untuk memecahkan } \\
\text { masalah }\end{array}$ & 28 & 75 \\
\hline 7 & $\begin{array}{l}\text { Mengerjakan tugas yang diberikan } \\
\text { oleh guru dan mampu membuat } \\
\text { simpulan sendiri tentang pelajaran } \\
\text { yang diterimanya }\end{array}$ & 31 & 75 \\
\hline 8 & Hasil belajar tuntas & & 69,37 \\
\hline
\end{tabular}

Keterangan: Nilai Presentase

$$
86-100 \%
$$

$75-85 \%$

$0-74 \%$
Kriteria

Baik

Cukup

Kurang

Sama dengan pelaksanaan pada siklus pertama, maka pada siklus kedua ini ada dua aspek yang ingin diukur yaitu penilaian proses pembelajaran dan hasil pembelajaran.

Tabel Hasil Observasi Siklus Pertama Partisipasi Siswa dala Proses Pembelajaran

\begin{tabular}{|c|l|c|c|}
\hline No & \multicolumn{1}{|c|}{ Aspek yang diamati penjelasan guru } & Jumlah Siswa & Persen \\
\hline 1 & $\begin{array}{l}\text { Mendengarkan } \\
\text { dengan tekun }\end{array}$ & 38 \\
\hline 2 & $\begin{array}{l}\text { Ada usaha dan motivasi untuk } \\
\text { mempelajari bahan pelajaran atau } \\
\text { stimulus yang diberikan oleh guru }\end{array}$ & 35 & 87,5 \\
\hline 3 & $\begin{array}{l}\text { Dapat menjawab pertanyaan yang } \\
\text { diberikan oleh guru dengan benar pada } \\
\text { akhir pelajaran }\end{array}$ & 35 & 87,5 \\
\hline 4 & $\begin{array}{l}\text { Dapat bekerja sama dan berhubungan } \\
\text { dengan siswa lain }\end{array}$ & 36 & 97,5 \\
\hline 5 & $\begin{array}{l}\text { Mengajukan pendapat, bertanya } \\
\text { berkomentar kepada guru dan siswa }\end{array}$ & 39 & 97,5 \\
\hline 6 & $\begin{array}{l}\text { Aktif berdiskusi untuk memecahkan } \\
\text { masalah }\end{array}$ & 39 & 83 \\
\hline 7 & $\begin{array}{l}\text { Mengerjakan tugas yang diberikan } \\
\text { oleh guru dan mampu membuat } \\
\text { simpulan sendiri tentang pelajaran } \\
\text { yang diterimanya }\end{array}$ & 39 & 93,43 \\
\hline 8 & $\begin{array}{l}\text { Hasil belajar tuntas } \\
\text { Rata-rata }\end{array}$ & 38 & \\
\hline
\end{tabular}


Keterangan: Nilai Presentase

$$
\begin{aligned}
& 86-100 \% \\
& 75-85 \% \\
& 0-74 \%
\end{aligned}
$$

\section{SIMPULAN}

a. Dari aspek partisipasi siswa dalam pembelajaran pada siklus kedua semua aspek mengalami peningkatan yang cukup signifika. Semua siswa sudah terlibat dan aktif berdiskusi untuk memecahkan masalah sudah mencapai 39 (97,5\%). Begitu juga kemampuan siswa untuk mengajukan pendapat, bertanya atau berkomentar kepada guru dan siswa dari 18 orang meningkat menjadi 39 orang $(97,5 \%)$. Kemampuan dan kemauan siswa untuk mengerjakan tugas yang diberikan oleh guru dan membuat simpulan sendiri tentang pembelajaran yang diterimanya juga meningkat menjadi $97,5 \%$ atau 39 orang siswa.

b. Pada siklus kedua, siswa yang dapat belajar tuntas sudah mencapai 39 orang (97\%). Secara ringkas dapat disimpulkan bahwa hasil siklus kedua dari aspek partisipasi/keaktifan siswa dalam proses pembelajaran sudah tercapai secara optimal, sebab rata-rata persentase yang dicapai sudah 93,43\%.

c. Pada siklus kedua, persentase ketuntasan belajar siswa juga meningkat yaitu dari 40 siswa
Kriteria

Baik

Cukup

Kurang

pada siklus pertama hanya 30 siswa yang termasuk dalam kategori sudah tuntas belajar menjadi 39 siswa. Sehingga pada siklus kedua ini persentase kelulusan siswa sudah mencapai 93,43\% artinya Metode pembelajaran Kooperatif Tipe STAD sudah dapat meningkatkan prestasi belajar siswa "Mendeskripsikan Kepatuhan Terhadap Hukum" bagi siswa kelas IX SMP Negeri 9 Tebing Tinggi.

\section{DAFTAR RUJUKAN}

Abdullah, A,E. 1989. Pokok-pokok Layanan Bimbingan Belajar. Ujung Pandang: Fakultas Ilmu Pendidikan IKIP Ujung Pandang.

Abdurrahman. H. 1990. Pengelolaan Pengajaran. Bandung Tarsito.

Anonim. 1998. Garis-Garis Besar Haluan Negara. Jakarta: Departemen Pendidikan Nasional.

Arikunto, S. 1993. Prosedur Penelitian dan Penilaian Hasil Belajar. Jakarta: Bina Aksara.

Ahmadi, Abu. 1998. Didaktik Metodik. Cet.II: Semarang:CV. Toha Putra.

Ali, M. 1993. Guru dan Proses Belajar Mengajar. Bandung: Sinar Baru Algensindo. 
Rahmawati Hasibuan : Upaya Meningkatkan ....

Boediono.1998. Pembinaan Profesi Guru dan Psikologi Pembinaan Personalia. Jakarta: Departemen Pendidikan dan Kebudayaan.

Bahri, D. S. 1994. Prestasi Belajar dan Kompetensi Guru. Surabaya: Usaha Nasional.

Edward, J. D. 1995. Statistik Matematika Moderm. Jakarta: PT. Gramedia Pustaka Utama.

Gie. 1995. Cara Belajar yang Efisien. Yogyakarta: Liberti.

Hardjana. 1994. Kiat Sukses di Perguruan Tinggi. Yogyakarta: Kanisius.

Hudoyo, H. 1984. Pengembangan Kurikulum. Surabaya: Usaha Nasional.
Loekomono. 1994. Belajar Bagaimana Belajar. Jakarta: BPK Gunung Mulia.

Mappa, S. 1970. Psikologi Pendidikan. Ujung Pandang: Fakultas Ilmu Pendidikan IKIP Ujung Pandang.

Mardanu. 1997. Peranan Orang Tua dalam Upaya Meningkatkan Mutu Pendidikan Anak. Jakarta: Cakrawala Pendidikan.

Muhtar. 1992. Pedoman Bimbingan Guru dalam Proses Belajar Mengajar. Jakarta: PGK \& PTK Dep.Dikbud.

Mathis dan Jacksin. 2002. Manajemen Sumber Daya Manusia. Jakarta: Salemba Empat. 